\title{
DAILY ACTIVITY OF THE EUROPEAN BADGER (MELES MELES, MUSTELIDAE, CARNIVORA) ON SETTS IN DARWIN RESERVE AND MESCHERA NATIONAL PARK (RUSSIA) IN SUMMER AND AUTUMN
}

\author{
Natalia V. Sidorchuk*, Viatcheslav V. Rozhnov \\ A.N. Severtsov Institute of Ecology and Evolution of RAS, Russia \\ *e-mail: sidorchukn@gmail.com
}

Received: 30.01 .2018

\begin{abstract}
The European badger's (Meles meles) daily activity was studied in two regions of European Russia with camera traps. The results of the study show that the daily activity of the European badger on settlements does not differ in the compared populations inhabiting Darwin Reserve and Meschera National Park. The badger appears on surface often during the daylight contrary to the classical idea of nocturnal activity of the species. More than half of all animal registrations occur at daylight during the summer. The moderate climate of the study areas and low level of human persecution are considered among the possible reasons of this type of activity. The daily activity of the European badger undergoes markedly seasonal changes in both populations. Badgers more often came out from their setts during daylight in summer and at night in autumn. The results have practical application in the organisation of the census of badgers by means of camera traps.
\end{abstract}

Key words: camera trap, daily activity, Darwin Reserve, Meles meles, Meschera National Park

\section{Introduction}

The European badger is the most studied species of the three species of the genus Meles. Most of the information on the biology and ecology of the European badger was obtained in European countries. The interest of European researchers is due to various reasons, both general theoretical, fundamental, and applied studies. The European badger has become one of the model species in the study of the behavioural ecology of predatory mammals, the emergence and evolution of their sociality due to the significant variability of the social and spatial organisation of populations of this species in different parts of the range and the absence of obvious reasons for the formation of a group lifestyle (Kruuk, 1978; Stopka \& Johnson, 2000; Macdonald et al., 2004). Such attention to the European badger from European researchers led to a detailed study of all aspects of the species ecology, including daily activity.

Daily activity of European badger was studied most extensively in the western part of its range, in those populations where animals were monitored by radio tracking or by numerous observations near settlements (Neal, 1948; Cresswell \& Harris, 1988; Fowler \& Racey, 1988; Tuyttens et al., 2001; Kowalczyk et al., 2003; Goszczyński et al., 2005; Rosalino et al., 2005; Do Linh San et al., 2007).

Data on the daily activity of the European badger in the eastern part of its range (the former USSR) are fragmentary (Heptner et al., 1967; Gorshkov, 1997;
Danilov \& Tumanov, 1976; Danilov, 2005; Soloviev, 2008). These studies were not systematic due to the laboriousness of observations. The researchers note that the European badger can be found on the surface at different time of the day, both at the settlement and at a distance from it. However, in modern encyclopedias badgers are still described as nocturnal animals (Blokhin et al., 2012).

In general, tasks of studies of the European badger ecology in the former USSR differ from those in European countries - for a long time they were determined by the hunting importance of the species. Despite the fact that badgers are hunted species in Russia, the population density of these species are counted rarely and irregularly. This is evidenced by the lack of publications on the density of populations of badgers in the territory of the Russian Federation in recent years.

Partly this is due to the fact that the estimation of population density of species of the genus Meles is labourious. It is necessary to determine a number of parameters using visual observations near settlements (for example, the average number of animals inhabiting one settlement, the average size of the litter). The use of camera traps can facilitate the work on the estimation of the badger population density. The use of camera traps has a number of advantages and is popular in zoological studies (Rozhnov \& Sidorchuk, 2016). Recently, methodical publications on the use of camera traps and on the processing and storage of data begin to ap- 
pear (O’Connell et al., 2011; Jackson et al., 2005; Ogurtsov et al., 2017).

The development of recommendations for the use of camera traps in the estimation of the badger population density is one of the tasks of our studies. The daily activity of the European badger must be taken into account during the estimation of the population density of this species. It is necessary to know aspects of the badger's daily activity during the period of planning observations in settlements both with the help of observers and with the help of camera traps. This will allow determining the number of animals inhabiting one settlement accurately. The results of studies on the daily activity of two species of the genus Meles in different populations show that in some populations it is better to carry out observations during daylight (Sidorchuk et al., 2014, 2016).

The aims of this work were to study the daily activity of the European badger on settlements in the Meschera National Park and compare the results with the nearest studied population in the Darwin Reserve. Similar studies were not conducted in the National Park earlier.

\section{Material and Methods}

Our study was carried out in two populations of the European badger in Darwin Reserve and Meschera National Park. Both study areas are located in the same climatic zone and have a similar relief.

Darwin Reserve is situated in north-western Russia. It is located on a peninsula surrounded by the waters of the Rybinsk reservoir. The reserve consists mostly of peat bogs and pine (Pinus sylvestris L.) forests. The climate of the Reserve is moderate with cool summers (average temperature of the warmest month $+17.4^{\circ} \mathrm{C}$ ) and moderately cold winters (average temperature of the coldest month $-12.2^{\circ} \mathrm{C}$ ) (Sidorchuk \& Rozhnov, 2010).

The National Park is located in the central part of the Meschera Lowland. Peat bogs occupied a quarter of the area of the National Park before economic development of this territory. Pine forests are the most common in the territory of the $\mathrm{Na}$ tional Park at present. The climate of the National Park is moderate with cool summers (average temperature of the warmest month $+18.4^{\circ} \mathrm{C}$ ) and moderately cold winters (average temperature of the coldest month $-11^{\circ} \mathrm{C}$ ) (Relief and geology, 2006).

Badger settlements in the Darwin Reserve are rarely visited by people. No one visited the badger settlements during our work except us. Badger settlements in the National Park are also rarely visited by people, since they are located in a specially pro- tected part of the park at a distance from the recreation zone. Inspectors of the National Park Protection Department occasionally visit the badger settlements . An additional factor of disturbance may be a dirt road which is located near one of the setts in the National Park. However, it is rarely used because it is located on the edge of a specially protected area of the National Park. We assume that the studied populations have small differences in the degree of anthropogenic anxiety, as they are under protection and animal hunting is prohibited.

We used camera traps of different models (Wild view Xtreme II, Leaf River DC-3BU and KeepGuard $690 \mathrm{NV}$ ) to study the daily activity of the European badger on setts (Sidorchuk et al., 2007). Camera traps were placed at badger setts near entrances that had intensive signs of their usage. We used a standard set for all camera traps without delay between photographs and 24-hour activity (day/night). The camera traps were attached to the tree trunks $1.5-2.0 \mathrm{~m}$ above the ground. This allowed us to avoid damage of camera traps and lashing belts by the raccoon dog (Nyctereutes procyonoides Gray, 1834). We placed only one camera trap on each sett. We checked camera traps every 14-20 days to replace batteries and to move the cameras to different part of the settlement if badgers started to use another entrance.

We conducted observations at nine locations (badger setts) in Darwin Reserve in 2006-2009. Each camera trap was kept for 6 month at the settlement (from May till October). Rarely we moved camera traps to another location if the initial observation settlement was abandoned by badgers. We selected for analysis data for the period from 01 June to 10 November. The total camera traps worked 1850 trap days. We got 678 badger shots for this period.

In Meschera National Park we conducted observations at two locations (badger setts) in summer and autumn of 2016-2017. Camera traps worked 107 trap days total. We got over 3270 badger shots for this period.

The difference in the number of photographs obtained in the two study sites can be explained by two reasons: the differences in the microrelief of the badger settlements and the number of animals inhabiting one settlement. In Darwin Reserve the soil conditions are unfavourable for sett construction and badgers dig their burrows in old charcoal pits, i.e. ring-shaped elevated grounds, which are remains of the charcoal trade of the $19^{\text {th }}$ century (Sidorchuk $\&$ Rozhnov, 2016). Entrances in such settlements are 
located on different sides of the shaft. Therefore, camera trap can capture animals only on a small part of the settlement near one entrance. In Meschera National Park badger settlements are situated on a flat surface. The area of the settlement on which camera trap captures animals is bigger than in the previous study area. Thus, animals can appear near the camera trap more often. In addition, settlements with camera traps in the Darwin Reserve were inhabited by single animals or pairs, while in Meschera National Park one of the settlements was inhabited by a group of four badgers.

We determined separate registrations of badgers' activity. We considered two photos of a badger with an interval of at least $30 \mathrm{~min}$. between them for two separate registrations. If we received a series of photographs when the animals were in the field of view of the camera trap for a long time (for example, during grooming, cleaning the settlement, preparing the litter), then we thought that all photos in the series were one registration (Fig. 1). We determined the time of this registration according to the data of the "middle» photo in a series (Sidorchuk \& Rozhnov, 2010). An example of such a series is shown in Fig. 1. The camera trap registered badgers for $39 \mathrm{~min}$. and took 19 shots during this period of time. We chose only 6 pictures with the most interesting animal behaviour to illustrate all the series. We consider the whole series of photos as one registration of badger's activity. We assign to this registration the time of the photo taken 19 min. after the start of the series at 05:50.
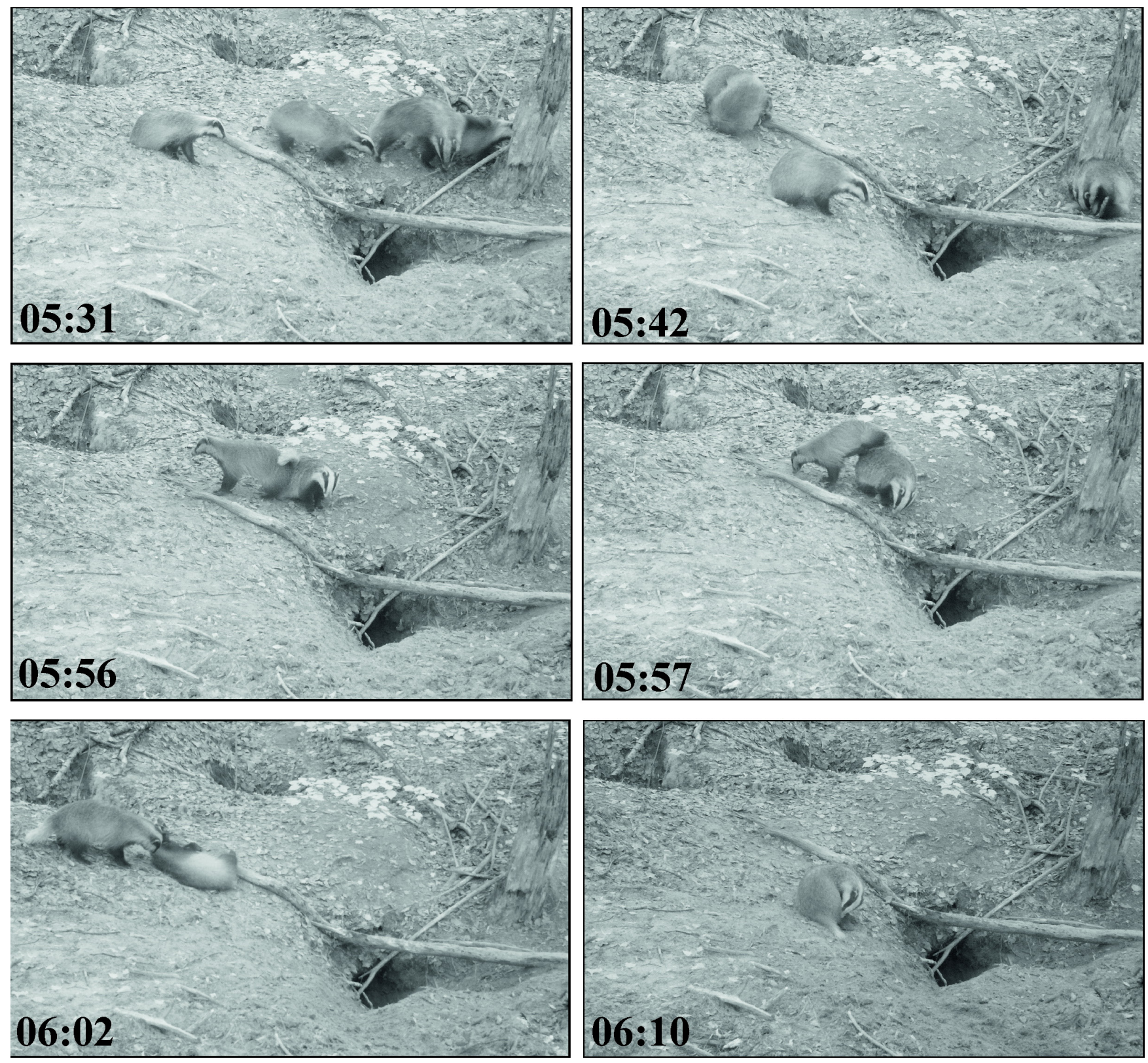

Fig. 1. Long activity of the European badger on sett during the daylight in the Meschera National Park. The camera trap fixed various interactions of animals: grooming, allogrooming and scent-marking of one animal by another. 
We identified 147 registrations from photographs from Darwin Reserve, and 165 registrations on photographs from Meschera National Park. We counted the number of registrations at different times of the day (morning, day, evening, and night). The duration of these periods varies throughout the year. We used data on the local time of sunrise and sunset to calculate the duration of the day and night. We calculated the duration of the morning and evening twilight as a percentage of the duration of the day. We determined the duration of twilight as the mean value between the duration of civil and navigational twilight (Rozhnov \& Sidorchuk, 2016). The duration of twilight was $15 \%$ of the day's duration for Darwin Reserve and $12 \%$ for Meschera National Park.

We used log-liner analysis (Quinn \& Keough, 2002) to test for the effects of study area and season on badger activity. The variables in the analysis were time of registration (morning, day, evening, and night), study area (Darwin Reserve or National Park) and season of registration (summer and autumn). All analyses were conducted using STATISTICA 13.0. All figures were prepared using CorelDRAW X7.

\section{Results}

We did not find inter-annual differences in the daily activity of the European badger in settlements in the Darwin Reserve $(\chi 2=8.04, p=0.23)$. Therefore the data from different years were combined for further analysis. The results of observations show that the badger in the Darwin
Reserve can appear on the surface at any time of the day (Fig. 2). Most often, animals were photographed at the sett entrances during daytime (63\% of all registrations). Animals often left shelters during the day and went out in search of food. Similar meetings were noted by the staff of the reserve in the zoological card file.

Badgers are rarely photographed on settlements at night. Only $10 \%$ of the registrations are made at night. The number of registrations in the morning and evening twilight is almost the same (13\% and $14 \%$ respectively).

Badgers activity distributed unevenly during the day. Camera traps photographed animals at sett entrances from 04:00 h. to 07:00 h. most often. Probably, badgers return to shelters after feeding at this time. Then the number of registrations decreases. The minimum of registrations is noted in the daytime hours from 10:00 h. to 14:00 h. Then the number of registrations gradually increases between 14:00 h. and 18:00 h. Evening peak of registrations falls in the period from 18:00 h. to 21:00 h. The evening peak of the badger activity is less obvious than the morning one. This is probably due to the fact that the time of animal emergence on the surface varies. The second minimum of animal registrations is observed from 22:00 h. to 3:00 h. Probably the badger is looking for food away from the setts at this time. The presence of badger registrations on the setts at dusk and night time suggests that animals can return to the setts in Darwin Reserve during feeding.

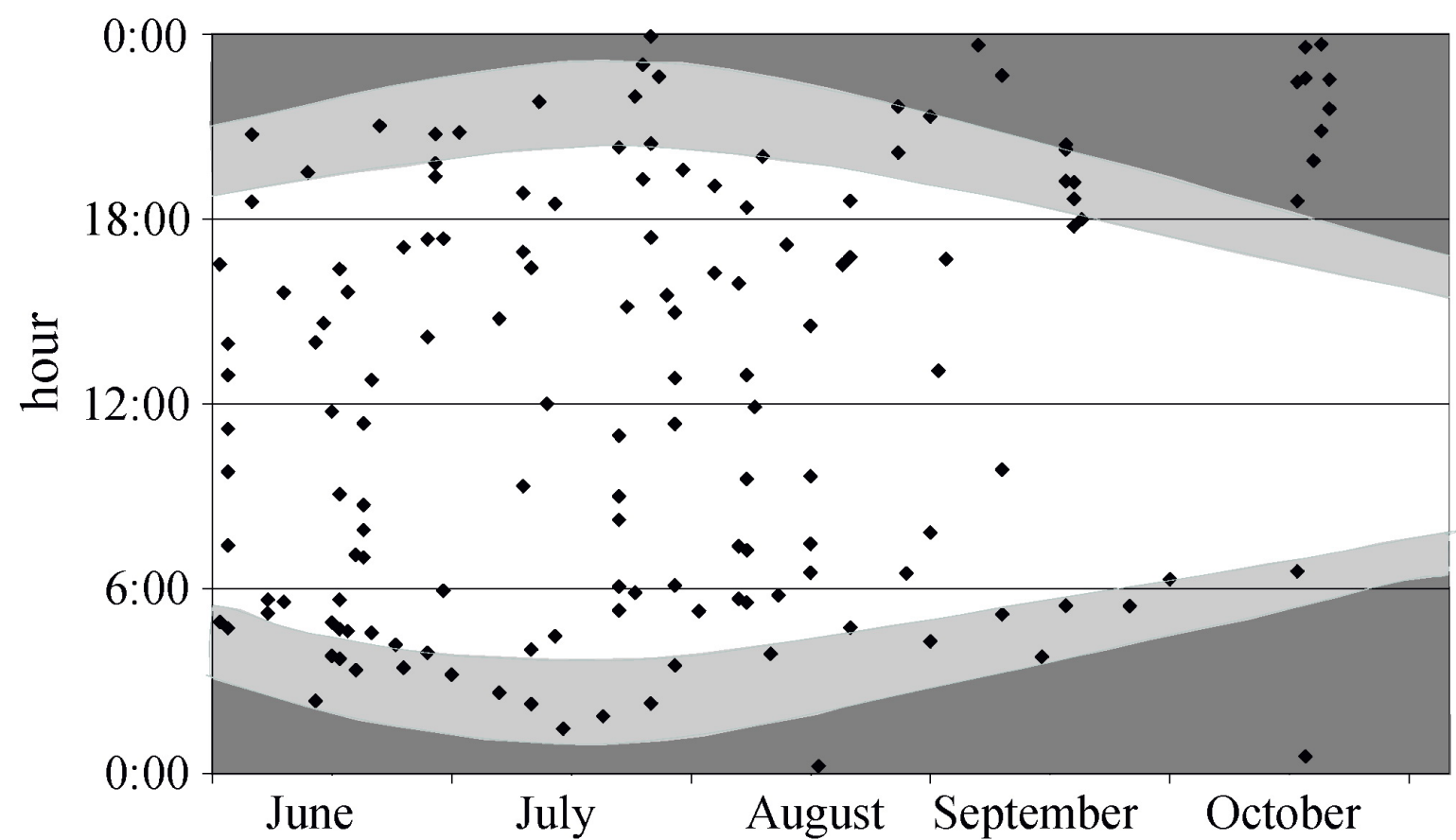

Fig. 2. Daily activity of the European badger at the entrances of settlements in the Darwin Reserve (night hours are marked in dark gray, twilight is marked light gray). 
The results of observations show that the badger in Meschera National Park can appear on the surface at any time of the day (Fig. 3). Most often, animals were photographed at sett entrances during daytime (59\% of all registrations). Badgers are rarely photographed on the settlements at night. Only $13 \%$ of registrations are made at night hours. The number of registrations in the morning and evening twilight is the same (14\%).

We have identified two peaks of badger activity on setts during the day. Animals were recorded at sett entrances from 4:00 h. to 6:00 h. most often. Probably, this period of time corresponds to the time when animals return to shelters after feeding. The number of registrations decreases from 6:00 h. The minimum of registration is recorded in the daytime hours from 7:00 h. to 17:00 h. Afterwards badgers become more active and number of registrations gradually increases to a maximum from 19:00 h. to 21:00 h., when animals go out for feeding. There is a second minimum of registrations from 21:00 h. to 3:00 h. Probably the badger is looking for food away from the setts this time.

We used log-liner analysis to test for the effects of the study area and season on badger activity. The three way interaction is not significant $\left(\chi^{2}=5.8, \mathrm{df}=3, \mathrm{p}=\right.$ $0.11)$. So only two way interactions are included in the analysis $\left(\chi^{2}=70.1, \mathrm{df}=7, \mathrm{p}=0.001\right)$. We include one two way interaction in the model (time $\times$ season, Table 1). The quality of our model does not differ significantly from the quality of the original full model $\left(\chi^{2}=14.4\right.$, $\mathrm{df}=8, \mathrm{p}=0.07)$. Thus, badgers have a similar structure of daily activity in both populations. The season affects the daily activity of the badger in the studied populations (Fig. 4). Standardised residuals showed that badgers in both populations showed more activity in day hours during summer than expected (Table 2). In autumn, badgers appear near sett entrances often at night. It should be noted that in the Darwin Reserve, badgers become nocturnal by the middle of September. In the Meschera National Park, this happens by the end of summer. We assume that the reason is an unequal amount of material collected in August in different populations. The camera trap in the Meschera National Park registered badgers rarely during the second half of August as the animals expanded their zone of activity at the settlement and began to use the entrances outside the field of view of the camera trap. We changed the location of the camera trap on the settlement during the planned camera check in late August which increased the number of received photos.

\section{Discussion}

The European badger is an animal with nocturnal activity in most European populations (Neal, 1948; Cresswell \& Harris, 1988; Fowler \& Racey, 1988; Tuyttens et al., 2001; Kowalczyk et al., 2003; Goszczyński et al., 2005; Rosalino et al., 2005; Do Linh San et al., 2007). Badger appears on the surface before sunset or immediately after it and returns before sunrise. However, cases of daytime activity have been noted in some populations also (Abelentsev, 1966; Heptner et al., 1967; Gorshkov, 1997; Danilov \& Tumanov, 1976; Danilov, 2005; Sitnikova, 2007; Soloviev, 2008; Rodrígues et al., 1996; Fedriani et al., 1999).

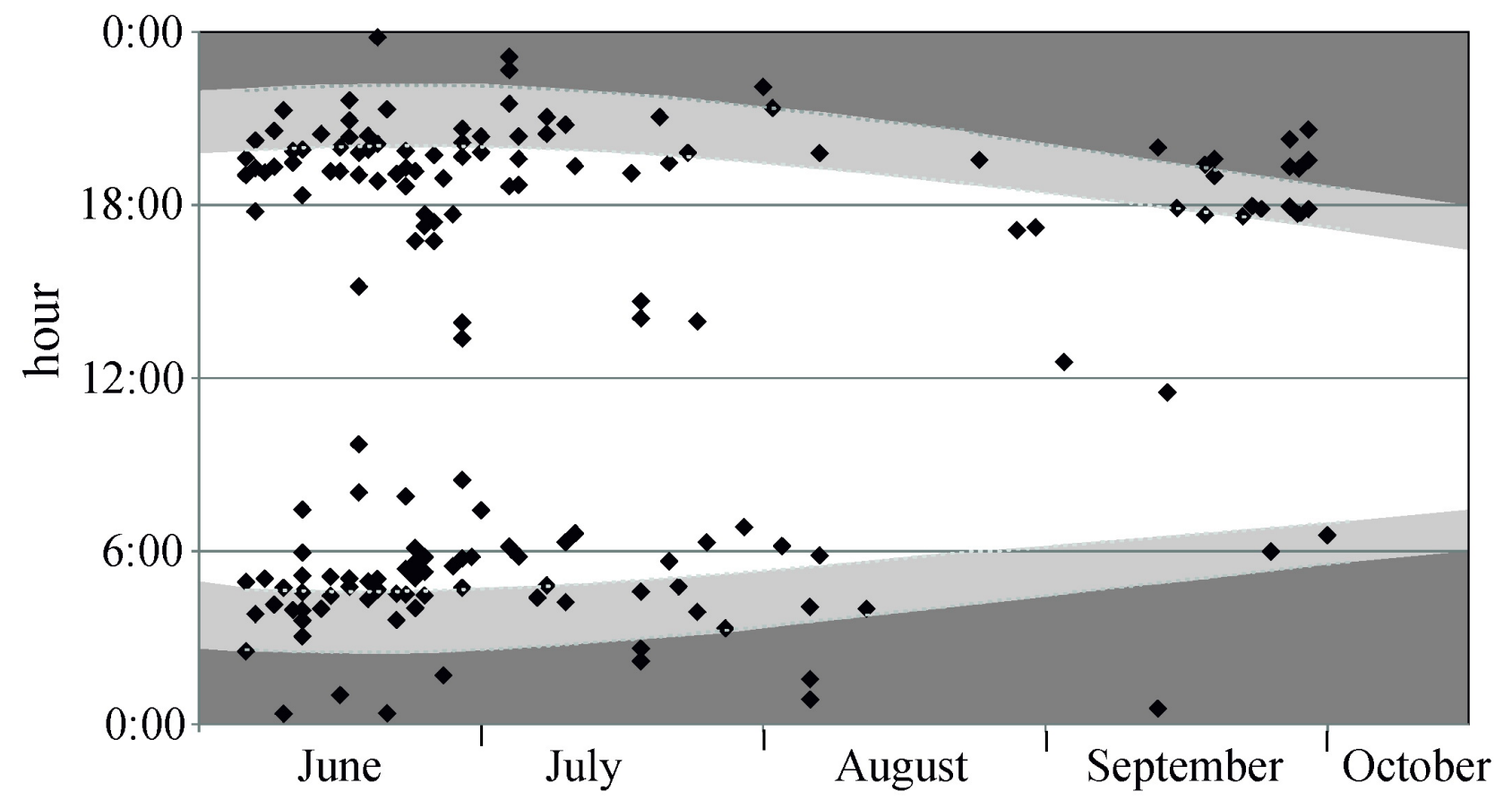

Fig. 3. Daily activity of the European badger at the entrances of settlements in the Meschera National Park (night hours are marked in dark gray, twilight is marked light gray). 
Table 1. The effects of study area and season of registration on badger activity

\begin{tabular}{|l|l|l|l|}
\hline \multicolumn{1}{|c|}{ Variables } & \multicolumn{1}{c|}{$\chi^{2}$} & \multicolumn{1}{c|}{ df } & \multicolumn{1}{c|}{$\mathrm{p}$} \\
\hline time $\times$ study area & 6.3 & 3 & 0.1 \\
\hline time $\times$ season & 64.7 & 3 & 0.001 \\
\hline study area $\times$ season & 3.7 & 1 & 0.05 \\
\hline
\end{tabular}

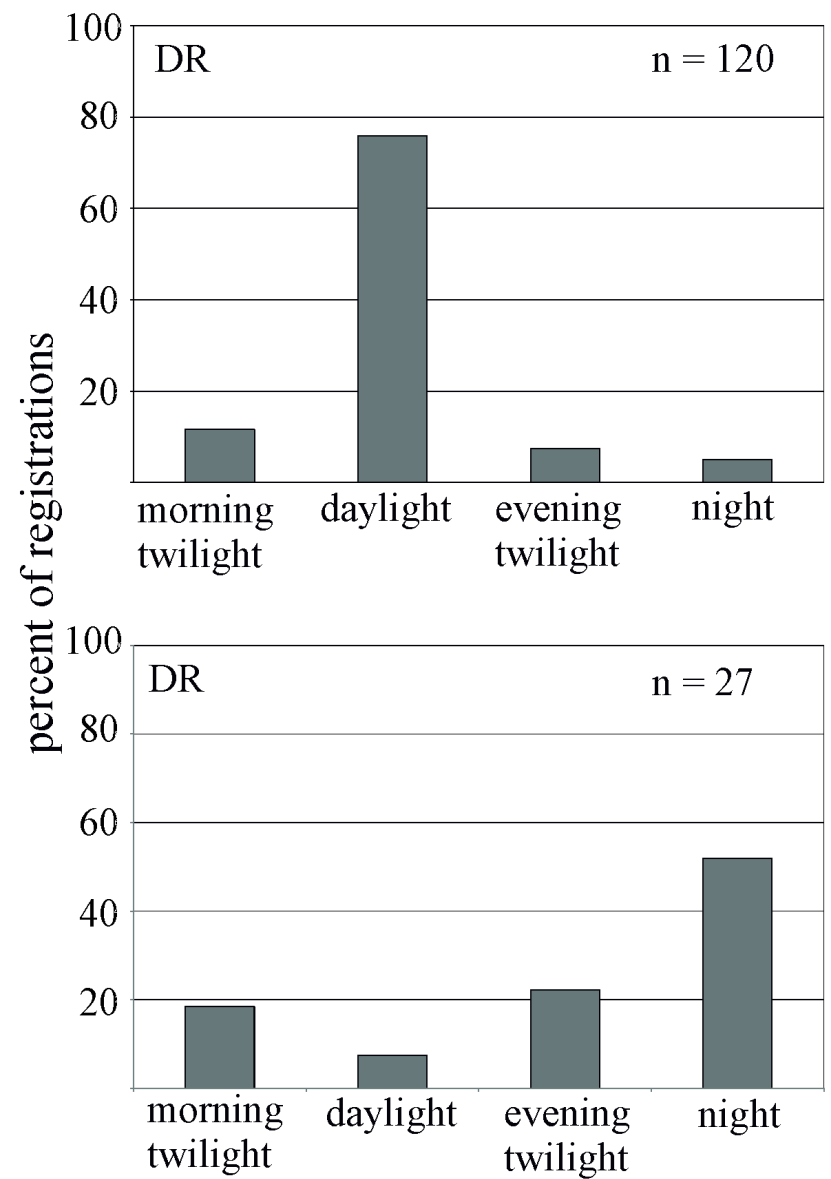

Table 2. Standardised residuals in model

\begin{tabular}{|l|l|l|l|l|}
\hline \multirow{2}{*}{ Season } & \multicolumn{4}{|c|}{ Time of registration } \\
\cline { 2 - 5 } & morning & \multicolumn{1}{|c|}{ day } & evening & night \\
\hline summer & -0.03 & 0.43 & -1.6 & -1.2 \\
\hline autumn & 0.75 & -0.75 & 0.0 & 0.72 \\
\hline
\end{tabular}
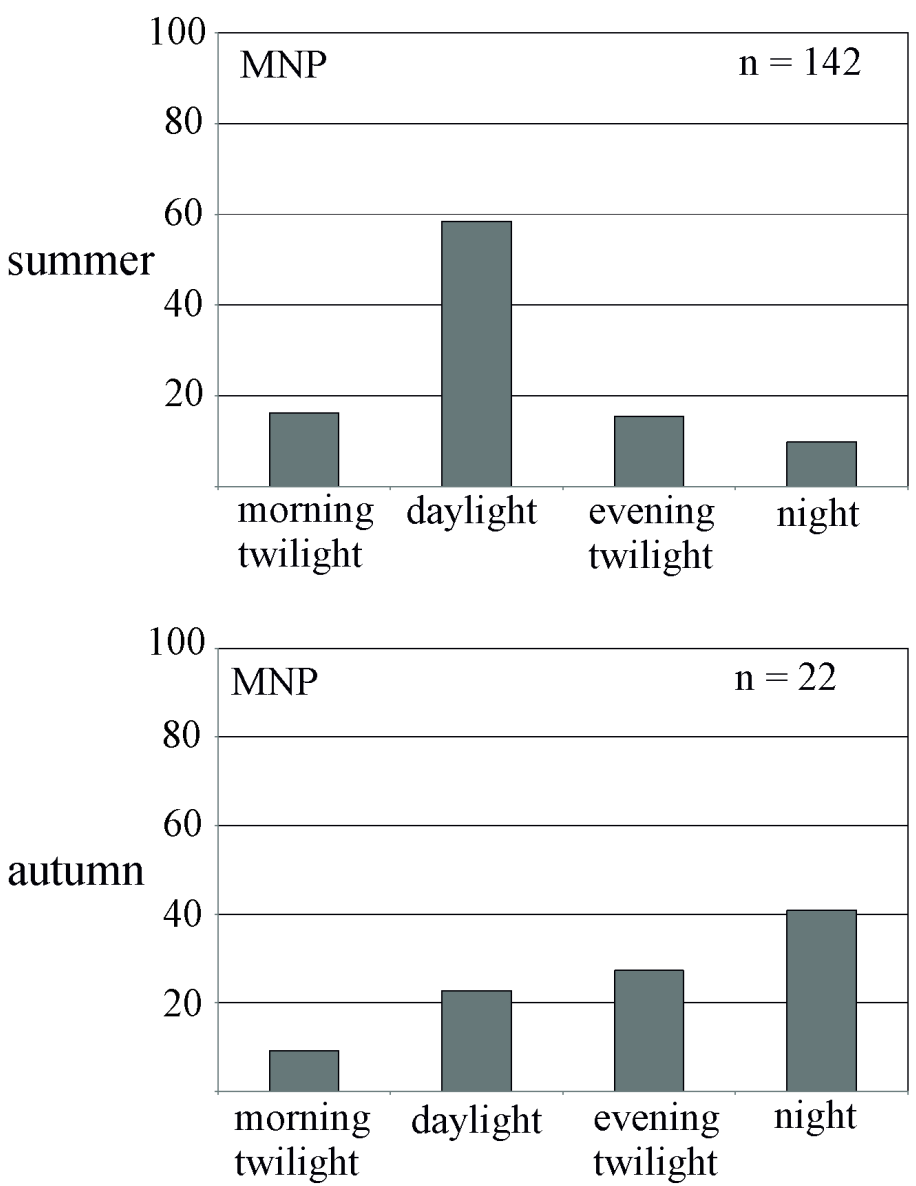

Fig. 4. Daily activity of the European badger at the entrances of settlements in the Darwin Reserve (DR) and the Meschera National Park (MNP) during different seasons.

Many researchers note a negative correlation between the duration of badger activity and the duration of daylight and the intensity of moonlight (Neal, 1948, Cresswell \& Harris, 1988, Fowler \& Racey, 1988). However, in some populations the European badger begins to leave the shelters before dark as the length of the daylight increases. Similar behaviour of animals is noted in the national park of Białowieża (eastern Poland). Polish researchers associate this fact with summer reduction in the number of earthworms the main food of badgers in this area. Badger has to spend more time searching for other food during this period. The badger has to leave the settlements before dawn with a decrease in the length of the night (Kowalczyk et al., 2003).

The results of our studies showed that the daily activity of the European badger in popula- tions of Darwin Reserve and Meschera National Park does not coincide with that in the European countries.

Weather conditions are considered among the factors determining the daily activity of the badger (Neal, 1948; Cresswell \& Harris, 1988; Fowler \& Racey, 1988), as well as human and predator impact (Goszczyński et al., 2005; Rosalino et al., 2005). However, the population density of the wolf (Canis lupus (Linnaeus, 1758)) and lynx (Lynx lynx (Linnaeus, 1758)) (the main predators of the badger) is not high in most of Europe. These predators are completely absent in some countries. Therefore, some researchers (Rosalino et al., 2005) doubt that predators can affect the daily activity of the badger.

It is interesting that the Asian badger Meles leucurus (Hodgson, 1847) in the Ussuriisky Re- 
serve often comes to the surface in the daytime (Sidorchuk et al., 2016), despite the fact that predators often visited settlements of the Asian badger in the Ussuriisky Reserve (Sidorchuk et al., 2015). It should be noted that the Asian badger in this population can rest near the entrances for a long time and even sleep on the surface despite the attention of predators. We never recorded such behaviour for the European badger in different populations of European Russia (Sidorchuk et al., 2014).

It should be noted that predators rarely come to badger setts in Darwin Reserve. Such visits were recorded six times during four years of observation (four visits of lynx and two visits of wolf) (Sidorchuk et al., 2015). Predators visited both inhabited and uninhabited badger settlements throughout the active period of the badger in the Reserve. Predators came to the settlements at different time of the day. Most of these visits (four of six) were at daylight hours. In addition, there are data on day meetings of reserve staff with a badger at a distance from the setts in the Reserve archive. Probably, such meetings are caused by the rarity of predator visits to the setts. It is also possible that the badger feels safe in the vicinity of the sett and can quickly take refuge in the nearest entrance.

We did not register visits of predators to the settlements of a badger in Meschera National Park. However, the camera traps recorded four visits of setts by stray dogs that spent several hours at the entrances, but contacts with the badger are not registered.

Probably, predators do not influence the activity of the badger on setts in both studied populations, because of the rarity of visits. It should be noted that in order to obtain more substantiated conclusions about the impact of predators on the badger's daily activity we need to achieve information about animal activity not only on settlements, but also within the entire home range.

In some populations, the nighttime activity of the European badger is a consequence of the climate and is not associated with illumination. For example, in Portugal, the daytime air temperature can reach $40^{\circ} \mathrm{C}$ and, accordingly, the nighttime activity of the badger is the consequence of choosing the most optimal temperature (Rosalino et al., 2005). Perhaps this factor is one of the defining factors for the population of the European badger in the Krasnodar region also (Sidorchuk et al., 2014). Probably, a cool climate can allow the daytime activity of the badger in the populations inhabiting the Darwin Reserve and the Meschera National Park.

The daily activity of a badger varies throughout the year (especially in areas where this animal falls into winter sleep). Different factors affect the daily activity of animals in different seasons. For example, Gorshkov (1997) notes that European badger often goes out for feeding at daytime on the territory of Tatarstan during spring. This is probably due to the recovery of the animal after winter sleep, during which the badger heavily loses weight (Danilov \& Tumanov, 1976; Gorshkov, 1997).

Cases of badger daytime activity during spring are common in Spain also (Doñana $\mathrm{Na}-$ tional Park), where the badger does not keep a winter sleep (Rodrígues et al., 1996). Spanish zoologists also note significant individual differences in the rhythm of daily activity: some animals are often active during the day, while others are almost never seen on the surface during the daytime. Badgers can often be found during the daytime in autumn in the north-west of Russia (Danilov \& Tumanov, 1976), in the Vyatka-Kama interfluve (Soloviev, 2008). Researchers attribute this fact to the animal's need for large amounts of food for fat stores.

The badger's daily activity also changes during the observation period in populations inhabiting Darwin Reserve and Meschera National Park. The nature of these changes is the same for both populations. Badger appears on setts during daylight more often in summer, and at night in autumn.

The fact that the European badger is rarely registered on setts during daylight in autumn is probably connected with the preparation of animals for winter sleep. Some researchers (Danilov \& Tumanov, 1976; Gorshkov, 1997) note that the European badger actively feeds in late summer and autumn, when it accumulates fat stores. Often a badger looks for food during the daytime, goes far from shelters, and accordingly is not fixed by camera traps on setts. The increase in the number of night registrations at this time is also associated with the preparation of settlements for winter sleep (cleaning tunnels and nesting chambers and preparing litter).

Human persecution is also an important factor affecting the daily activity of a badger. Tuyttens et al. (2001) compared the time of animals' exit from settlements in two regions of England and noted that in a population affected by hu- 
mans, animals appear on the surface later. Neal (1948) also gives an example of such a relation. He noted that in a place for a long time rarely visited by human, a badger can be found at sett entrances even in the afternoon. Goszczyński et al. (2005) believe that the nighttime activity of a badger in central Poland is caused by human persecution. However, the badger often appears on the surface during the daylight hours in the protected area of the Białowieża National Park (eastern Poland) (Goszczyński et al., 2005). We noted that the Asian badger in the Ussuriisky Reserve often comes to surface during the daytime also (Sidorchuk et al., 2016).

This factor can have a significant impact on the daily activity in badger populations in Darwin Reserve and Meschera National Park. Badger often appears on the surface during the daytime in these populations with a protected area regime.

Using camera traps allowed us to obtain extensive, systematic material on the daily activity of badgers in the settlements. However, we need to have information about the activity of animals not only in the settlements, but also within the entire habitat to identify factors that determine the character of the daily activity of badgers, its duration and seasonal changes. In addition, Cresswell \& Harris (1988) noted that the physiological state of animals (for example, participation in reproduction) and social interactions in the group also have a great influence on the activity of the badger. The study of the influence of all possible factors requires the application of more complex and costly methods of study.

The specific features of the daily activity of the European badger must be taken into account during estimation the population density of this species. You can determine the number of animals that occupy one settlement using camera traps. Colour photographs obtained during daylight can be used for individual recognition of individuals (Sidorchuk et al., 2011; Pankova, 2016; Rozhnov \& Sidorchuk, 2016). The European badger is active most often during the dark in autumn in both studied populations. So we received few photos suitable for individual identification of badgers in this season of the year. This means that it will be harder to determine the number of animals living in one shelter with such photos. Our results show that it is better to install camera traps in June and July to obtain photographs suitable for individual identification of animals.

\section{Conclusions}

The results of our studies show that the daily activity of the European badger on settlements does not differ between the two compared populations. Animals appear on the surface of settlements during the daylight often both in the Darwin Reserve and in Meschera National Park. We assume that this behaviour of animals is due to the absence of human persecution and the moderate climate of study areas. The daily activity of the European badger undergoes markedly seasonal changes in both populations. Badgers more often came out from their setts during daylight in summer and at night in autumn. Thus, it is necessary to take into account the climate of study area and probability of human persecution during planning of observations on badger settlements. Observations can also be carried out in the daytime in regions with a moderate climate and/or low level of human persecution.

\section{Acknowledgments}

The authors are grateful to the Directorate of the Darwin Reserve and the Meshera National Park, as well as the inspector of the National Park E.N. Demyanov and Deputy Director of the National Park V.N. Zheltukhin for help in survey organisation. Camera traps for research in the Meshera National Park are provided by «Project "Forest Monitoring"» within the work of the All-Russia contest "Camera Trap 2015». This study was funded by the Presidium of the Russian academy of sciences, Program №41 «Biodiveristy of natural systems and biological resources of Russia».

\section{References}

Abelentsev V.I. 1966. Ecology and economic value of badger in Ukraine. In: Ecology and history of fauna of vertebrates in Ukraine. Kiev: Naukova dumka. P. 73-89. [In Russian]

Cresswell W.J., Harris S. 1988. The effect of weather conditions on the movements and activity of badgers (Meles meles) in a suburban environment. Journal of Zoology 216(1): 187-194. DOI: 10.1111/j.14697998.1988.tb02424.x

Danilov P.I., Tumanov I.L. 1976. Mustelids of north-west of USSR. Leningrad: Nauka. 256 p. [In Russian]

Danilov P.I. 2005. Hunting animals of Karelia: the environment, resources, management, protection. Moscow: Nauka. 340 p. [In Russian]

Do Linh San E., Ferrari N., Weber J.-M. 2007. Spatio-temporal ecology and density of badgers Meles meles in the Swiss Jura Mountains. European Journal of Wildlife Research 53(4): 265-275. DOI: 10.1007/s10344-006-0085-8

Blokhin G.I., Alpatov V.V., Bagaturov M.F., Bagaturova A.A., Berezin M.V., Blokhina T.V., Vasenkov D.A., Vershinina T.A., Zhigarev I.A., Kartsev V.M., Kidov A.A., Kornilova M.B., Lavrov E.A., Malovichko L.V., Martynov 
A.V., Matushkina K.A., Petrovnin S.V., Spasskaya N.N., Tkacheva E.Yu., Shatalova S.P. Encyclopedia of Animals. 2012. M.: ROOSSA. 704 p. [In Russian]

Fedriani J.M., Palomares F., Delibes M. 1999. Niche relations among three sympatric Mediterraean carnivores. Oecologia 121(1): 138-148. DOI: 10.1007/s004420050915

Fowler P.A., Racey P.A. 1988. Overwintering strategies of the badger, Meles meles, at $57^{\circ}$ N. Journal of Zoology 214(4): 635-651. DOI: 10.1111/j.1469-7998.1988.tb03763.x

Gorshkov P.K. 1997. Badger in the ecosystems of the Tatarstan Republic. Kazan: Tabigat. 176 p. [In Russian]

Goszczyński J., Juszko S., Pacia A., Skoczyńska J. 2005. Activity of badgers (Meles meles) in Central Poland. Mammalian Biology - Zeitschrift für Säugetierkunde 70(1): 1-11. DOI: 10.1078/1616-5047-00171

Jackson R., Rodney M., Jerry D.R., Wangchuk R., Hunter D.O. 2005. Surveying snow leopard populations with emphasis on camera trapping: a handbook. Sonoma, California. 158 p.

Heptner V.G., Naumov N.P., Yurgenson P.B., Sludskiy A.A., Chirkova A.F., Bannikov A.G. 1967. Mammals of the Soviet Union. Vol. 2. Part 1. Moscow: Vysshaya Shkola. 1004 p. [In Russian]

Kowalczyk R., Jędrzejewska B., Zalewski A. 2003. Annual and circadian activity patterns of badgers (Meles meles) in Bialowieza Primeral Forest (eastern Poland) compared with other Palaearctic populations. Journal of Biogeography 30(3): 463-472. DOI: 10.1046/j.13652699.2003.00804.x

Kruuk H. 1978. Spatial organization and territorial behaviour of the European badger Meles meles. Journal of Zoology 184(1): 1-19. DOI: 10.1111/j.1469-7998.1978.tb03262.x

Macdonald D.W., Newman C., Dean J., Buesching C.D., Johnson P.J. 2004. The distribution of Eurasian badger, Meles meles, setts in a high-density area: field observations contradict the sett dispersion hypothesis. Oikos 106(2): 295-307. DOI: 10.1111/j.0030-1299.2004.12879.x

Neal E. 1948. The Badger. London: Collins. 155 p.

O’Connell A.F., Nichols J.D., Karanth K.U. (Eds.). 2011. Camera Traps in Animal Ecology: Methods and Analyses. Springer Japan. 271 p. DOI: 10.1007/978-4-431-99495-4

Ogurtsov S.S., Volkov V.P., Zheltukhin A.S. 2017. Review of some actual methods of storage, processing and analysis of data from camera traps in zoological research. Nature Conservation Research 2(1): 73-98. DOI: 10.24189/ncr.2017.057 [In Russian]

Pankova N.L. 2016. Experience of using camera traps in studying the state of the Asian badger population in the Natural Park «Samarovsky Chugas» (Western Siberia). In: Theriofauna of Russia and adjacent territories ( $X$ Congress of Theriological society). Proceedings of the International conference. Moscow: KMK Scientific Press Ltd. P. 313. [In Russian]

Quinn G.P., Keough M.J. 2002. Experimental design and data analysis for biologists. New York: Cambridge University Press. 537 p.

Relief and geology. In: Meschera National Park. 2006-2017. Available from: http://www.park-meshera.ru/about/ Relef_i_geologiya. Retrieved on 27 January, 2018.
Rodrígues A., Martín R., Delibes M. 1996. Space use and activity in a Mediterranean population of badgers Meles meles. Acta Theriologica 41(1): 59-72. DOI: 10.4098/AT.arch.96-5

Rosalino L.M., Macdonald D.W., Santos-Reis M. 2005. Activity rhythms, movements and patterns of sett use by badgers, Meles meles, in a Mediterranean woodland. Mammalia 69(3-4): 395-408. DOI: 10.1515/ mamm.2005.031

Rozhnov V.V., Sidorchuk N.V. 2016. Behavioural ecology of badgers. Experience in data collection by means of camera traps. Moscow: KMK Scientific Press Ltd. 104 p. [In Russian]

Sidorchuk N.V., Volchenko A.E., Rozhnov V.V. 2007. Experience of using camera traps in studying the behavioural ecology of badger Meles meles. In: Theriofauna of Russia and adjacent territories (VIII Congress Theriological society). Proceedings of the International conference. Moscow: KMK Scientific Press Ltd. P. 455. [In Russian]

Sidorchuk N.V., Rozhnov V.V. 2010. European badger in the Darwin reserve. Traditional and new methods in studying of ecology and behaviour of denning predators. Moscow: KMK Scientific Press Ltd. 122 p. [In Russian]

Sidorchuk N.V., Volchenko A.E., Rozhnov V.V. 2014. Daily activity of the European badger (Meles meles Linnaeus, 1758) (Mustelidae, Mammalia) at settlements in several populations of European Russia. Povolzhsky Ecological Journal 4: 601-610. [In Russian]

Sidorchuk N.V., Maslov M.V., Rozhnov V.V. 2011. The experience of European and Asian badger individual identification by means of camera traps. In: Remote methods of research in zoology. Proceedings of the conference. Moscow: KMK Scientific Press Ltd. P. 86. [In Russian]

Sidorchuk N.V., Maslov M.V., Rozhnov V.V. 2015. Role of badger setts in life of other carnivores. Studia Ecologiae et Bioethicae 13(1): 81-95.

Sidorchuk N.V., Rozhnov V.V., Maslov M.V. 2016. The daily activity of the Asian badger (Meles leucurus amurensis Schrenck 1859) in the settlements in the Ussuriisk reserve. Proceedings of Petrozavodsk State University 155(2): 42-48. [In Russian]

Sitnikova E.F. 2007. Daily activity of badger female ( $\mathrm{Me}$ les meles) and badger cubs. In: IV All-Russian Conference on animal behaviour. Proceedings of the conference. Moscow: KMK Scientific Press Ltd. P. 134. [In Russian]

Soloviev V.A. 2008. Biology and economic significance of badgers of the Vyatka-Kama interfluve. $\mathrm{PhD}$ Thesis. Balashikha. 23 p. [In Russian]

Stopka P., Johnson D.D.P. 2000. Badger (Meles meles) as a model species for the development of ecological and behavioural research. Lynx 31(2): 125-131.

Tuyttens F.A.M., Stapley N., Steward P.D., Macdonald D.W. 2001. Vigilance in badgers Meles meles: the effects of group size and human persecution. Acta Theriologica 46(1): 79-86. DOI: 10.1007/BF03192419 
СУТОЧНАЯ АКТИВНОСТЬ ЕВРОПЕЙСКОГО БАРСУКА (MELES MELES, MUSTELIDAE, CARNIVORA) НА ПОСЕЛЕНИЯХ В ДАРВИНСКОМ

\title{
ЗАПОВЕДНИКЕ И НАЦИОНАЛЬНОМ ПАРКЕ «МЕЩЕРА» (РОССИЯ) В ЛЕТНЕ-ОСЕННИЙ ПЕРИОД
}

\author{
Н. В. Сидорчук*, В. В. Рожнов \\ Институт проблем экологии и эволющии имени А.Н. Северцова РАН, Россия \\ *e-mail: sidorchukn@gmail.com
}

\begin{abstract}
Изучение суточной активности европейского барсука проводили с помощью фотоловушек в двух популяциях Европейской России. Результаты исследований показывают, что суточная активность европейского барсука на поселениях не отличается в Дарвинском заповеднике и национальном парке «Мещера». Показано, что вопреки классическим представлениям о сумеречно-ночном характере активности вида, барсук в исследованных популяциях может появляться на поверхности и в светлое время суток. Больше половины всех регистраций животных приходится на день. Среди возможных причин подобного характера активности рассматриваются особенности климата, а также низкая степень антропогенной нагрузки районов исследований. Суточная активность европейского барсука подвержена сезонным изменениям. Результаты исследования имеют практическое применение при организации учета численности европейского барсука. А именно при выборе сроков проведения наблюдений за животными на поселениях.
\end{abstract}

Ключевые слова: Meles meles, Дарвинский заповедник, национальный парк «Мещера», суточная активность, фотоловушка 